\title{
INTEGRATING DUCTS INTO THE CONDITIONED SPACE: SUCCESSES AND CHALLENGES
}

\author{
Jeffrey Siegel \\ Department of Civil Engineering, The University of \\ Texas at Austin, Austin, TX 78712-1076
}

\begin{abstract}
In residential and light commercial construction in the United States, heating and cooling ducts are often located outside the thermal or pressure boundary of the conditioned space. This location is selected for aesthetic and space requirement reasons. Typical duct locations include attics, above dropped ceilings, crawlspaces, and attached garages. A wide body of literature has found that distribution system conduction and air leakage can cause $30-40 \%$ energy losses before cooling and heating air reaches the conditioned space. Recent innovative attempts at locating ducts in the conditioned space have had mixed results in terms of improving duct efficiency. Some of these strategies include cathedralizing attics (sealing and insulating at the attic roofline) and locating ducts in interstitial spaces. This paper reviews modeling studies that suggest substantial savings could be realized from these strategies and presents field measurements which reveal that construction planning and execution errors can prevent these strategies from being widely applied or from being effective when they are applied. These types of problems will need to be overcome for effective integration of ducts into the conditioned space.
\end{abstract}

$\begin{array}{ll}\text { NOMENCLATURE } \\ D E & \text { delivery efficiency }(\%) \\ E_{\text {cap }} & \text { air conditioner capacity (W) } \\ h & \text { enthalpy of air }(\mathrm{J} / \mathrm{kg}) \\ Q & \text { air flow rate }\left(\mathrm{m}^{3} / \mathrm{s}\right) \\ \rho & \text { density of air }\left(\mathrm{kg} / \mathrm{m}^{3}\right)\end{array}$

\section{INTRODUCTION}

Over the last decade, researchers, home builders, and policy-makers have placed increasing emphasis on the performance of heating and cooling ducts. Duct losses, especially when ductwork is located outside of the conditioned space, can cause significant comfort concerns, high bill complaints, increased peak electricity demand, and degradations in heating and cooling system performance. Duct air leakage has also been implicated in indoor air quality problems including backdrafting of combustion appliances, causing vehicle exhaust to enter the living space, and transporting pollutants (including moisture) from unconditioned to conditioned spaces. Duct losses can cause comfort problems including "cold blow" from heating registers and inadequate

\author{
lain Walker \\ Indoor Environment Program, Lawrence Berkeley National \\ Laboratory, Berkeley, CA 94720
}

distribution of conditioned air as well as mold and other IAQ problems from condensation of humid air on cold duct surfaces.

These problems, particularly the energy consequences, have lead to increased study of the impacts of duct efficiency. This research has lead to several novel test methods for duct leakage (Francisco and Palmiter, 2001; Walker et al., 2001) and duct efficiency (Olson et al., 1993). These test methods allow the quantification of the energy consequences of duct losses and have lead several energy utilities, state governments, and the federal government to initiate programs to increase duct efficiency. Members of American Society of Heating, Refrigeration, and Air-Conditioning Engineers (ASHRAE) have proposed a standard for measuring duct efficiency (Proctor, 1998; Francisco and Palmiter, 2000; ASHRAE, 2002, Siegel et al., 2003). Once approved, proposed ASHRAE standard 152P will likely be adopted into several state and local building codes. Further research has demonstrated that sealing and/or insulating ducts leads to improved duct efficiency (Palmiter et al., 1995; Jump et al., 1996; Siegel et al., 1998).

Distribution system research has also led many building professionals to consider the importance of locating heating and cooling ducts in the conditioned space. This consideration, although seemingly an obvious solution to the problem of low duct efficiency, has many detractors. Common objections to locating ducts in the conditioned space include aesthetics, cost concerns, and resistance to changes in current building practices. Furthermore, a standard practice in the HVAC industry has been to oversize heating and cooling systems to account for duct losses and other system degradations. Larger heating and cooling equipment typically results in greater profit for installers and hence there is little incentive to change current practices.

However, several building professionals have strived for a solution that minimizes the energy consequences of duct losses and does not cause other problems. The challenge is to locate ducts inside of the primary thermal (insulation) and pressure (air barrier) boundaries of a building. Common interior duct locations include wall and ceiling soffits, interior partition walls, and conditioned crawlspaces, attics, and basements (e.g. Treidler and Modera, 1996). This paper examines two interior duct locations, cathedralized attics and floor cavities to provide insight into the effectiveness of these duct locations and challenges to their implementation.

Attics are conventionally vented to prevent moisture problems in cold climates. In winter, warm humid air from inside a building can leak and contact a cold surface in an attic. If the surface is below the dew point of the air, the water will 
condense and a moisture problem can result. Building codes typically require $1 \mathrm{ft}^{2}$ of vent area for every $150 \mathrm{ft}^{2}$ or $300 \mathrm{ft}^{2}$ of roof surface area. This high amount of vent area leads to high air exchange rate and is designed to remove humid air from an attic before it causes a moisture problem. It is a strategy that is primarily designed to avoid condensation on cold attic surfaces in the winter in heating climates. However, in many climates in the United States, there is little chance of a moisture problem occurring because the surface temperature of attic spaces never gets below the dew point of the inside air. Furthermore, building assemblies can be designed to dry to both the inside and the outside should unusually cold outdoor conditions or humid inside conditions lead to condensation. In appropriate climates, several builders have started designing buildings that have unvented or cathedralized attics (Rudd and Lstiburek, 1998). These attics have no intentional venting to the outside, are insulated at the roofline and not at the attic floor as in conventional attic construction, and are intentionally vented to the inside of the home. Although this strategy has a greater surface area to the outside for heat transfer and a bigger volume of air to condition, these relatively small increases in energy use are offset by the benefits of capturing duct losses.

To evaluate the efficiency gains of cathedralized attics, we conducted modeling studies of ducts in conventional and cathedralized attics in Sacramento, an appropriate climate for cathedralized attics (Siegel et al., 2000). On the summer design day for Sacramento, the attic in the conventionally designed home was $20^{\circ} \mathrm{C}\left(36^{\circ} \mathrm{F}\right)$ hotter than the cathedralized attic. The homes with cathedralized attics were predicted to have a faster response to thermostat changes, better equipment performance, and a $25-50 \%$ reduction in cooling energy use. The greater the duct losses, the more effective cathedralized attics were at regaining the conditioning energy. Similar results have been shown for other climates and suggest that venting attics is an energy efficient strategy.

Another strategy to minimize duct losses is to locate ducts in conditioned interstitial spaces such as between floors, in ceiling soffits, above dropped ceiling in insulated and sealed ceiling cavities. There is relatively little research that presents measured data to evaluate these strategies in residential buildings, but recent duct research has expanded beyond residential buildings and has started to examine ceiling space configurations and duct efficiency penalties. Although still largely preliminary, data suggests that locating the ducts outside of the conditioned space (both thermal and pressure envelopes) can have significant energy penalties in light commercial buildings (Withers et al., 1996; Cummings and Withers, 1998, Delp et al., 1998) Further research on the air tightness of dropped ceilings suggests that they are quite leaky as a primary air barrier indicating that buildings that rely on the dropped ceiling to be the primary air barrier will have high infiltration loads, require excessively sized equipment, and use considerably more energy.

The purpose of this paper is to present measured data to evaluate whether ducts located in conditioned spaces have improved efficiencies. The measured data was collected in 9 homes in California and Nevada. The focus is on residential systems, although similar measurements could be completed in light commercial buildings. The overall goal of this research is to investigate the benefits of locating ducts in interior spaces.

\section{METHODS}

The chosen metric for evaluating the efficiency of duct systems in the house is the delivery efficiency (DE). The DE is a measure of how much enthalpy comes out of the registers and grills as compared to the enthalpy in the air stream at the supply plenum. A house with poor ducts will have a low DE because of energy losses (heating) or gains (cooling) will decrease or increase the enthalpy of air that comes out of the supply registers. DE does not include cycling effects, interactions between the duct system and the equipment, or heating/cooling that enters the conditioned space through other paths besides the grills.

$$
\begin{aligned}
& \text { Delivery efficiency is calculated as: } \\
& D E=\frac{\sum_{i} Q_{i} \rho_{i}\left(h_{i}-h_{\text {inside }}\right)}{E_{\text {cap }}}
\end{aligned}
$$

where: DE is the delivery efficiency

$i$ is an index that goes from 1 to the number of supply registers

$Q_{i}$ is the air flow rate through supply register $i\left(\mathrm{~m}^{3} / \mathrm{s}\right)$,

$\rho_{i}$ is the density of air flowing through supply register $i\left(\mathrm{~kg} / \mathrm{m}^{3}\right)$,

$h_{i}$ is the enthalpy of air flowing through supply register $i(\mathrm{~J} / \mathrm{kg})$,

$h_{\text {inside }}$ is the enthalpy of air in the interior of the building $(\mathrm{J} / \mathrm{kg})$, and

$E_{c a p}$ is the measured air conditioning capacity (W).

The diagnostic tests performed at each house to get the inputs for Eq. 1 are:

- System fan flow (using the procedures in proposed ASHRAE 152P)

- Individual register flows (using a fan assisted flow hood technique)

- Continuous measurement of room, register, duct plenum, buffer zone, and outdoor temperatures and relative humidities

Additional measurements conducted at each house included:

- Duct leakage using fan pressurization tests (using the procedures in proposed ASHRAE 152P)

- Measurement of duct surface area, and observation of duct type, location, and insulation

More details about these tests are given in Walker et al. (1998a, 1998b and 1999).

\section{RESULTS AND DISCUSSION}

Eleven houses were monitored for this project: two houses in Palm Springs, CA (sites PS1 and PS2), one house in Mountain View, CA (site MV3), two houses in Sacramento, CA (sites SA4 and SA5), a single house in Cedar Park, TX (site TX6), and five houses in Las Vegas, NV (sites LV7 - 11). All of the houses were new and unoccupied, except for MV3, which was new and recently occupied, and LV7, which was built approximately 10 years ago. Such a small number of houses were not considered to be a statistically valid sample of all new houses but they do present a fairly wide range of different conditions. General information about these houses is 
summarized in Table 1. Two sites, SA4 and TX6 are excluded from this paper because of problems with their measured DEs. More details about these exclusions can be found in Siegel et al. (2003).

\begin{tabular}{|c|c|c|c|}
\hline Site & Location & \multicolumn{2}{|c|}{$\begin{array}{l}\text { Floor Area } \\
\mathbf{m}^{2}\left(\mathrm{ft}^{2}\right)\end{array}$} \\
\hline PS1 & Palm Springs, CA & 134 & $(1440)$ \\
\hline PS2 & Palm Springs, CA & 134 & $(1440)$ \\
\hline MV3 & Mountain View, CA & 155 & $(1670)$ \\
\hline SA5 & Sacramento, CA & 94 & $(1010)$ \\
\hline LV7 & Las Vegas, NV & 120 & $(1300)$ \\
\hline LV8 & Las Vegas, NV & 223 & $(2400)$ \\
\hline LV9 & Las Vegas, NV & 188 & $(2030)$ \\
\hline LV10 & Las Vegas, NV & 223 & $(2400)$ \\
\hline LV11 & Las Vegas, NV & 186 & $(2010)$ \\
\hline
\end{tabular}

The location of the supply ducts, return ducts and air handler, as well as the duct surface areas in unconditioned spaces are given in Table 2. Almost all of the homes in the study had all of the ducts located in the attic. The two exceptions were MV3 which had the return ducts in the garage and the supply ducts between the first and second floors, and TX6 which had some return ducting in an interior closet. All of the systems were constructed with plastic flex duct with R-4 (RSI-0.7) glass fiber insulation and had sheet metal or ductboard supply plenums. The return plenums were usually just an air handler cabinet, but in MV3 a wood and gypsum wallboard box was built as a platform return for the air handler. Four of the Las Vegas houses were built with cathedralized attics with no intentional roof venting. The attic insulation in these homes was directly under the roof deck. This attic design should have a significant impact on duct effectiveness because the ducts are more in the conditioned space than in a conventional house with a vented attic and the insulation on the attic floor.

Table 2: Duct Locations

\begin{tabular}{lccc}
\hline Site & $\begin{array}{c}\text { Supply Duct } \\
\text { Location }\end{array}$ & $\begin{array}{c}\text { Return Duct } \\
\text { Location }\end{array}$ & $\begin{array}{c}\text { Air Handler } \\
\text { Location }\end{array}$ \\
\hline PS1 & Attic & Attic & Attic \\
PS2 & Attic & Attic & Attic \\
MV3 & Between Floors & Garage & Garage \\
SA5 & Attic & Attic & Attic \\
LV7 & Attic & Attic & Attic \\
LV8 & Sealed Attic & Sealed Attic & Sealed Attic \\
LV9 & Sealed Attic & Sealed Attic & Sealed Attic \\
LV10 & Sealed Attic & Sealed Attic & Sealed Attic \\
LV11 & Sealed Attic & Sealed Attic & Sealed Attic \\
\hline
\end{tabular}

Duct leakage measurements were made in each of these houses using the two fan pressurization techniques from proposed ASHRAE Standard 152P. The first test simply pressurizes the duct system and determines the total duct leakage. The second technique also pressurizes the house to determine the duct leakage to outside. The duct leakage results appear in Table 3. The leakage fraction is the ratio of of the leakage flow at operating conditions to the air flow through the air handler. Leakage fractions are described in more detail in Proposed ASHRAE Standard 152P (ASHRAE, 2002).

Table 3: Duct Leakage

\begin{tabular}{lcccccc}
\hline & & & \multicolumn{3}{c}{ Leakage Fractions } \\
\cline { 5 - 7 } Site & Air Handler & To Outside & \multicolumn{2}{c}{ Total } \\
\cline { 5 - 7 } & \multicolumn{2}{c}{ Flow } & Sup. & Ret. & Sup. & Ret. \\
& $\mathbf{m}^{\mathbf{3}} / \mathbf{s}$ & $\mathbf{( C F M )}$ & & & & \\
\hline PS1 & & & & & & \\
PS2 & 0.878 & $(1861)$ & $4 \%$ & $4 \%$ & $8 \%$ & $6 \%$ \\
MV3 & 0.926 & $(1962)$ & $4 \%$ & $2 \%$ & $7 \%$ & $4 \%$ \\
SA5 & 0.71 & $(1504)$ & $15 \%$ & $16 \%$ & $22 \%$ & $18 \%$ \\
LV7 & 0.595 & $(1260)$ & $8 \%$ & $8 \%$ & $10 \%$ & $10 \%$ \\
LV8 & 0.652 & $(1381)$ & $7 \%$ & $2 \%$ & $7 \%$ & $3 \%$ \\
LV9 & 0.917 & $(1944)$ & $3 \%$ & $1 \%$ & $9 \%$ & $1 \%$ \\
LV10 & 0.828 & $(1755)$ & $4 \%$ & $2 \%$ & $8 \%$ & $8 \%$ \\
LV11 & 0.687 & $(1455)$ & $4 \%$ & $1 \%$ & $8 \%$ & $1 \%$ \\
& 0.501 & $(1061)$ & $2 \%$ & $1 \%$ & $9 \%$ & $5 \%$ \\
Average & & & & & & \\
\hline
\end{tabular}

These houses had on average, $6 \%$ supply duct leakage to the exterior and 10\% total supply leakage. The return side showed similar results: on average $4 \%$ to the exterior and $6 \%$ total. These ducts are less leaky than houses that LBNL has measured in the past, e.g., Jump et al. (1996) measured an average of $17 \%$ supply and $17 \%$ return leakage for 25 houses in California. Walker (1998) summarizes duct leakage measurements by other researchers that were of a similar magnitude to Jump et al. (1996). The average leakages for houses with interior ducts was very similar to those with exterior ducts.

Delivery effectiveness measurements at steady state conditions were made in each of the houses. In some houses, multiple tests were conducted. The results appear in Table 4.

Table 4: Duct Efficiency

\begin{tabular}{cccc}
\hline Site & $\begin{array}{c}\text { No. of } \\
\text { tests }\end{array}$ & $\begin{array}{c}\text { Measured } \\
\text { Delivery } \\
\text { Efficiency }\end{array}$ & $\begin{array}{c}\text { Supply } \\
\text { Duct } \\
\text { Location }\end{array}$ \\
\hline PS1 & 1 & $88 \%$ & Exterior \\
PS2 & 1 & $76 \%$ & Exterior \\
MV3 & 2 & $88 \%$ & Interior \\
SA5 & 5 & $82 \%$ & Exterior \\
LV7 & 3 & $91 \%$ & Exterior \\
LV8 & 3 & $82 \%$ & Interior \\
LV9 & 3 & $89 \%$ & Interior \\
LV10 & 3 & $83 \%$ & Interior \\
LV11 & 3 & $82 \%$ & Interior \\
& & & \\
Average Exterior & $\mathbf{8 4 \%}$ & \\
Average Interior & $\mathbf{8 5 \%}$ & \\
\hline
\end{tabular}


On the 5 houses with unvented attics, we report a slightly higher cooling DE for cooling systems in interior spaces compared to 4 houses with ducts in exterior location. We expected a much bigger efficiency gain for interior ducts and thus conducted further investigations. For the homes with cathedralized attics (LV8-LV11), we used a blower door to conduct series leakage measurements to measure the leakage between the house and the attic and the attic and the outside in each of these homes. Analysis of these tests suggest two conclusions 1)the attics were as leaky to outside as they were to the house 2)the overall leakage area, equivalent to an unintentional vent area, was about $1 \mathrm{ft}^{2}$ of venting for every 500 $\mathrm{ft}^{2}$ of roof area. This is tighter than a conventional attic, but is not really unvented. No simultaneous measurements were made between house with conventional attics and houses with cathedralized attics, but the cathedralized attics were warmer than models of sealed attic construction would suggest (the models indicate that attic temperatures should be very close, within $2{ }^{\circ} \mathrm{C}$, to indoor temperatures), indicating that the attic leakage was bringing some hot outside air into the conditioned space. Further conversations with construction crews indicated that sealing the attic was a difficult and unfamiliar job because of the complexity of surfaces involved. Techniques for sealing were still being perfected. Sealed attics constructed build by the same builder in California two years later had slightly larger leaks to the outside (Sherman and Walker, 2002), indicating that construction issues are still an ongoing concern.

In site MV3, the ducts were located in the floor cavity between the first and second story. The duct leakage at this home was the highest of any of the homes in the study (see Table 3). The modeled delivery efficiency for this home was $75 \%$ (Siegel et al., 2003) suggesting serious efficiency degradation as a result of the leakage. However, measured delivery efficiency was $89 \%$ which suggests relatively minor energy consequences for such high leakage.

A more careful examination of this house suggested both successes and challenges to placing ducts in the conditioned space. Even though there was significant supply duct leakage, there was not a very large degradation in duct efficiency. Given that the delivery efficiency metric only includes energy that enters the conditioned spaces through the registers, much of supply duct losses would be regained in the space through conduction and leakage from the duct through the floor and the ceiling, thus improving the system efficiency even more. However, the space between the floors was well within the insulation boundary for the house, but only partially within the pressure boundary. Although a complete inspection was not possible, it seems likely that the primary air barrier was non-existent or compromised on one of the exterior walls at the location where the floor intersected the wall. Thus, even though the ducts were surrounded by conditioned space, the full improvement in duct efficiency was not realized. More careful construction detailing of the air barrier would have made this space truly conditioned.

\section{CONCLUSIONS}

In this study, we examined duct efficiency in five houses with ducts in interior locations (cathedralized attics and interstitial floor cavities) and four homes with ducts in exterior locations (conventional attics). The measured delivery efficiency was, on average, about the same for these houses suggesting that interior locations do not necessarily improve delivery efficiency. In all of the interior duct locations, the degradations in delivery efficiency come from the fact that the duct locations are not really conditioned and are not within the pressure boundary of the house.

From an energy efficiency standpoint it is always preferable to put ducts in the conditioned space. However, the challenge is making sure that conditioned space is really conditioned space. The primary thermal and pressure boundary of the house needs to be designed at the construction stage for the house and should be verified using pressure diagnostics and thermal testing. Constructability concerns, such as the complexity of sealing cathedralized attics need to be addressed before the energy gains of interior ducts can be fully realized.

The problems associated with exterior ducts are not limited to residential buildings. The largest complaint associated with duct losses in light commercial buildings have been linked to distribution issues, rather than energy complaints. Inefficient duct work, particularly duct leakage, can lead to insufficient flow through supply registers (Delp et al., 1998). This leads to rooms far away from the air handler being under-conditioned and can lead to rooms close to the air handler being over-conditioned, particularly if the conditioning equipment is controlled with a central thermostat. Locating ducts in the conditioned space does not mitigate this problem because even if energy that leaks to or from the ducts ultimately enters the space, it does not do so where conditioning is need

As we move into the second decade of distribution system research, architectural engineers need to consider arguments for interior ducts which do not relate to energy savings. Homeowners, builders, heating and cooling equipment contractors, and building occupants are increasingly sensitive to indoor air quality and comfort concerns. The inadequate conditioning of spaces because of duct leakage, condensation and mold growth on duct surfaces, transport of pollutants into the conditioned space all may elicit more of willingness for stakeholders to invest in interior ducts and duct sealing and insulating. Locating ducts within the conditioned space, as well as limiting excessive duct leakage, allows for minimization or elimination of these problems.

\section{REFERENCES}

ASHRAE. 2002. Second Public review Draft of Proposed ASHRAE Standard 152P - Method of test for Determining the Design and Seasonal Efficiencies of Residential Thermal Distribution Systems. Atlanta: American Society of Heating, Refrigerating and Air-Conditioning Engineers, Inc.

Cummings J B, Withers C R. (1998) Building cavities used as ducts: air leakage characteristics and impacts in light commercial buildings. ASHRAE Transactions, 104(2),743-752.

Delp W W., Matson N E., Tschudy E., et al. (1998) Field investigation of duct system performance in California light commercial buildings. ASHRAE Transactions, 104(2), 722-732.

Francisco P.W, Palmiter L. (2001) The nulling test: A new measurement technique for estimating duct leakage in residential homes ASHRAE Transactions, 107(1), 297-303. 
Francisco P W, Palmiter L. (2000) Field validation of Standard 152P. ASHRAE Transactions, 106(2), 771-783.

Jump D, Walker I S, Modera M P. (1996) Field Measurements of Efficiency and Duct Retrofit Effectiveness in Residential Forced Air Distribution Systems. Proc. ACEEE Summer Study 1996, 1.147-1.157.

Olson, J. et al. (1993) Field Measurements of the Heating Efficiency of Electric Forced-Air Systems in 24 Homes. Prepared by Ecotope, Inc. for the Washington State Energy Office under Contract No. 90-05-12.

Palmiter, L., J. Olson, and P. Francisco. 1995. Measured Efficiency Improvements from Duct Retrofits on Six Electrically-Heated Homes. Prepared by Ecotope, Inc. for Electric Power Research Institute under report TR-104426.

Proctor J P. (1998) Verification test of ASHRAE Standard 152P. ASHRAE Transactions, 104(1B), 1402-1410.

Rudd, A F., Lstiburek, J.W. (1998) Vented and Sealed Attics in Hot Climates. ASHRAE Transactions, 104(2), 1199-1210.

Sherman, M.H. and Walker, I.S. (2002). Residential HVAC and Distribution Research Implementation. Lawrence Berkeley National Laboratory report \#47214.

Siegel, J., Walker, I., and Sherman, M. (2000) Delivering Tons to the Register: Energy Efficient Design and Operation of Residential Cooling Systems. Proceedings from the 2000 ACEEE Summer Study on Energy Efficiency in Buildings, 1.295-306.

Siegel, J, McWilliams, J. and Walker, I. (2003) Comparison Between Predicted Duct Effectiveness from Proposed ASHRAE Standard 152P and Measured Field Data for Residential Forced Air Cooling Systems, ASHRAE Transactions 109 , in press.
Siegel, Jeffrey, Davis R, Francisco P, et al. (1998) Measured Heating System Effficiency Retrofits in Eight Manufactured (HUD Code) Homes. Proc. ACEEE Summer Study 1998, 2.189-2.201

Treidler B., Modera M P. (1996) Thermal performance of residential duct systems in basements. ASHRAE Transactions, 102(1), 847-858.

Walker I, Sherman M, Modera M, et al. (1998a). Leakage Diagnostics, Sealant Longevity, Sizing and Technology Transfer in Residential Thermal Distribution Systems. Berkeley: Lawrence Berkeley National Laboratory report \#41118.

Walker I, Sherman M, Siegel J, et al. (1998b) Leakage Diagnostics, Sealant Longevity, Sizing and Technology Transfer in Residential Thermal Distribution Systems: Part II. Berkeley: Lawrence Berkeley National Laboratory report \# 42691.

Walker I. (1998c) Technical Background for Default Values used for Forced Air Systems in Proposed ASHRAE Standard 152P. ASHRAE Transactions, 104(1B), 1360-1375.

Walker I, Sherman M, Siegel J. (1999). Distribution Effectiveness and Impacts on Equipment Sizing. Berkeley: Lawrence Berkeley National Laboratory report \#43724.

Walker I S, Sherman M H, Wempen J et al. (2001) Development of a New Duct Leakage Test: Delta Q. Lawrence Berkeley National Laboratory report \#47308.

Withers C R., Cummings J B., Moyer N A. et al. (1996) Energy savings from repair of uncontrolled airflow in 18 small commercial buildings. ASHRAE Transactions, 102(2), 549561. 